\title{
Penerapan Strategi Pembelajaran Card Sort Kolaborasi Small Group Discussion Sebagai Upaya Meningkatkan Motivasi dan Prestasi Belajar Pendidikan Kewarganegaraan
}

\author{
Aisah¹, Nunuk Suryani², Siti Sutarmi Fadhilah ${ }^{3}$ \\ aisahsolo@gmail.com
}

\begin{abstract}
Citizenship is a lesson got from the elementary school to college level of education. It emphasizes on nation character building in order to be a well citizen which is putting his/ her right and obligation along with the constitution and law. Citizenship education is applied at all levels of education by means of developing knowledge obtained previously in order to be active at the instructional process for further level of education. In order to reach the goal as mentioned above, it is needed a teacher who knows in how to teach well by appltying convenient method towards its level and students' capability. Facilities also play very important role to support the on going curriculum. It is necessary for the teacher to make a lesson plan before teaching the class. By doing so, the instructional process will run well and he. She will be able to develop their creativity as well with the students. They must have passion and motivation to to learn as the teachers will feel proud to give better for them. The topic of protection and human rights watch is one of the topics of citizenship lesson learnt in Junior High School Grade VII on the second semester in SMP Negeri 3 Surakarta.
\end{abstract}

Keywords:. Learning Strategy, Card Sort collaboration, Small Group Disscussion, Motivation, learning outcomes

\footnotetext{
${ }^{1}$ Mahasiswa Magister Teknologi Pendidikan Universitas Sebelas Maret Surakarta

2 Dosen Universitas Sebelas Maret Surakarta

${ }^{3}$ Dosen Universitas Sebelas Maret Surakarta
} 


\section{PENDAHULUAN}

$\mathrm{P}$ emahaman siswa tentang materi Pelaksanaan perlindungan dan penegakan hak asasi manusia (HAM) sangat kurang. Hal ini dikarenakan motivasi dan prestasi belajar siswa pada waktu mengikuti materi ini, baik dalam bertanya maupun menjawab pertanyaan sangat kurang. Jumlah siswa dalam satu kelas adalah 32 siswa. Dari jumlah siswa tersebut hanya 12 orang yang aktif dalam mengikuti materi perlindungan dan penegakan hak asasi manusia (HAM) baik yang bertanya dan berpendapat serta menjawab pertanyaan. Sementara itu sebanyak 20 siswa tidak aktif dalam mengikuti materi tersebut. Keadaan tersebut menjadi lebih buruk oleh kurangnya kreativitas guru dalam menggunakan strategi pembelajaran. Berdasarkan latar belakang masalah di atas, maka dapat dirumuskan suatu permasalahan sebagai berikut: "Apakah penggunaan metode Card Sort kolaborasi Small Group Discussion dapat meningkatkan motivasi dan prestasi belajar dalam proses pembelajaran Pendidikan Kewarganegaraan materi perlindungan dan penegakan hak asasi manusia (HAM) pada siswa kelas VII.3 SMP Negeri 3 Surakarta Semester II Tahun Ajaran 2014/2015?". Adapun tujuan dari penelitian ini adalah adalah untuk meningkatkan motivasi dan prestasi belajar dalam proses pembelajaran PKn pada siswa kelas VII.3 SMP Negeri 3 Surakarta Semester II Tahun Ajaran 2014/2015 melalui penggunaan metode Card Sort kolaborasi Small Group Discussion. Untuk meningkatkan konsentrasi dalam proses pembelajaran PKn pada siswa kelas VII.3 SMP Negeri 3 Surakarta Semester II TahunAjaran 2014/2015. Untuk meningkatkan pemahaman dalam proses pembelajaran PKn pada siswa kelas VII.3 SMP Negeri 3 Surakarta Semester II Tahun Ajaran $2014 / 2015$.

Manfaat dari penelitian ini adalah mendapatkan teori baru untuk meningkatkan motivasi dan prestasi belajar dalam proses pembelajaran PKn pada siswa kelas VII.3 SMP Negeri 3 Surakarta. Hasil penelitian ini dapat digunakan sebagai dasar untuk kegiatan penelitian selanjutnya. Manfaat bagi guru: untuk mengetahui motivasi dan prestasi belajar dan pemahaman siswa kaitannya dengan materi perlindungan dan penegakan hak asasi manusia (HAM). Manfaat bagi siswa: untuk memfokuskan motivasi dan prestasi belajar serta pemahaman siswa pada materi pelajaran sehingga prestasi yang diperoleh juga bagus. Manfaat bagi sekolah: sebagai input yang bermanfaat untuk pertimbangan dalam melaksanakan program kegiatan belajar siswa di masa yang akan datang.

Strategi merupakan suatu rencana tindakan yang berbentuk tatanan langkah yang menggunakan upaya ranah cipta untuk mencapai tujuan tertentu. Pengertian Strategi Pembelajaran. Menurut Darmasyah (2010), pengertian strategi pembelajaran yaitu cara pengorganisasian isi pelajaran, penyampaian pelajaran dan pengelolaan kegiatan belajar dengan menggunakan berbagai sumber belajar yang dapat dilakukan guru untuk mendukung terciptanya efektivitas dan efisiensi proses pembelajaran. Strategi Pembelajaran Card Sort. Dalam buku Silberman (2001), dijelaskan bahwa Card Sort merupakan kegiatan kolaboratif yang bisa digunakan untuk mengejakan konsep, penggolongan sifat, fakta tentang suatu objek, atau mengulangi informasi. Gerakan fisik yang diutamakan dapat membantu untuk memberi energi kepada kelas yang telah letih. Kelebihan strategi pembelajaran Card Sort antara lain: mampu menumbuhkan kegembiraan dalam kegitan belajar mengajar. Materi yang disampaikan akan lebih menarik perhatian siswa. Mampu menciptakan suasana belajar yang aktif dan menyenangkan bagi siswa. Mampu meningkatkan hasil belajar siswa untuk mencapai taraf ketuntasan belajar. Penilaian dilakukan bersama pengamat dan pemain. Kekurangan strategi pembelajaran Card Sort antara lain: membutuhkan waktu yang lama bagi siswa untuk menyelesaikan tugas dan mencari jawaban. Guru harus meluangkan waktu yang lebih. Waktu untuk membuat persiapan lebih lama. Guru harus memiliki jiwa demokratis dan ketrampilan yang memadai dalam mengelola kelas. Menuntut sifat tertentu dari siswa atau kecenderungan untuk bekerja sama dalam menyelesaikan masalah. Suasana 
kelas menjadi "gaduh" sehingga dapat mengganggu kelas lain. Langkah-langkah dan prosedur Card Sort adalah sebagai berikut: setiap peserta didik diberi potongan kertas yang tercakup dalam satu atau contoh yang tercakup dalam satu atau lebih kategori: Karakteristik hadis sahih; Nouns, verbs, adverbs, dan preposition; Ajaran Mu'tazilah. Mintalah peserta didik untuk bergerak dan berkeliling di dalam kelas untuk menemukan kartu dengan kategori yang sama. (Anda dapat mengumumkan kategori tersebut sebelumnya atau membiarkan peserta didik menemukannya sendiri. Peserta didik dengan kategori yang sama diminta mempresentasikan kategori masing-masing di depan kelas.

Seiring dengan presentasi dari tiap-tiap kategori tersebut, berikan poin-poin penting terkait materi pelajaran. Menurut Sunaryo (1989), pengertian Small Group Discussion atau diskusi kelompok kecil ialah suatu proses yang teratur yang melibatkan sekelompok individu dalam suatu interaksi tetap muka secara kooperatif untuk tujuan membagi informasi, membuat keputusan dan memecahkan masalah. Menurut Sunaryo (1989), kelebihan strategi pembelajaran Small Group Discussion atau diskusi kelompok kecil, antara lain: kelompok memiliki sumber yang lebih banyak daripada individu. Anggota kelompok sering diberi masukan dari anggota yang lain. Anggota kelompok diskusi sering diberi motivasi oleh anggota yang lain, yang berusaha agar sumbangan pikiran bermanfaat untuk keberhasilan kelompok. Kelompok dapat menghasilkan keputusan yang lebih baik. Dalam banyak hal kelompok dapat menghasilkan keputusan dengan kualitas yang tinggi dari keputusan yang dihasilkan oleh anggota yang sama tetapi bekerja sendiri-sendiri. Anggota kelompok memiliki ikatan yang kuat tehadap keputusan yang diambil dengan melalui keterlibatannya dalam diskusi. Partisipasi dalam diskusi akan meningkatkan rasa saling mengerti antar individu dan sosial. Menurut Sunaryo (1989), kekurangan strategi pembelajaran Small Group Discussion atau diskusi kelompok kecil, antara lain: memerlukan waktu yang relatif banyak dibandingkan dengan pengambilan keputusan secara individual (diskusi memakan waktu lama). Pemborosan waktu, terutama bila terjadi hal-hal yang bersifat negative (apabila tidak mendapat pengarahan yang jelas siswa akan bingung). Diskusi dapat menekan pendirian. Ada bahaya bila dalam diskusi kelompok kecil beberapa anggotanya menyetujui terhadap pendapat dari anggota yang lebih aktif atau pintar. Langkah-langkah strategi pembelajaran Small Group Discussion atau diskusi kelompok kecil, antara lain: bagilah kelas kedalam beberapa kelompok kecil. Berikan bacaan untuk masing masing kelompok. Minta mereka untuk mendiskusikan bacaan. Mintalah setiap kelompok untuk menunjuk juru bicara. Minta para juru bicara kelompok untuk mempresentasikan hasil diskusi kelompoknya. Mintalah kelompok lain untuk bertanya atau menanggapi. Guru memberikan rangkuman atau penguatan-penguatan materi.

Kelebihan kolaborasi strategi pembelajaran Card Sort dengan Small Group Discussion. Menurut Wallace (1998) sebagaimana dikutip oleh Madya (2007) mengidentifikasikan kelebihan penelitian tindakan kolaboratif dari segi kedalaman dan cakupan, validitas dan reliabilitas, serta motivasi sebagaimana dijelaskan berikut ini: Kedalaman dan cakupan, semakin banyak orang yang terlibat dalam proyek penelitian tindakan, semakin banyak data yang dikumpulkan. Validitas dan reliabilitas, dengan melibatkan orang lain, akan lebih mudah melakukan penyelidikan terhadap suatu persoalan dari sudut yang berbeda. Motivasi, jika terjadi dinamika kelompok yang benar, maka bekerja sebagai anggota tim akan lebih bersemangat daripada bekerja sendiri. Kelemahan kolaborasi strategi pembelajaran Card Sort dengan Small Group Discussion yaitu membutuhkan waktu yang lama bagi siswa untuk menyelesaikan tugas dan mencari jawaban. Guru harus meluangkan waktu yang lebih. Waktu untuk membuat persiapan lebih lama. Guru harus memiliki jiwa demokratis dan ketrampilan yang memadai dalam mengelola kelas. Menuntut sifat tertentu dari siswa atau kecenderungan untuk bekerja sama dalam menyelesaikan masalah. Suasana kelas menjadi "gaduh" sehingga dapat mengganggu kelas lain. 
Langkah-langkah pelaksanaan kolaborasi strategi pembelajaran Card Sort dengan Small Group Discussion. Langkah-langkah pelaksanaan Kolaborasi Strategi Pembelajaran Card Sort dengan Small Group Discussion antara lain: Guru membuat potongan kertas sejumlah peserta didik yang ada di dalam kelas; Kertas-kertas tersebut dibagi menjadi dua bagian yang berbeda dengan bagian pertama berjumlah 5 buah dan kedua 12 buah; Kertas yang sejumlah 5 tadi kemudian ditulisi dengan pernyataan dan sisanya merupakan jawabannya; Jumlah pernyataan tersebut digunakan untuk menentukan jumlah kelompok, dan jawabannya menentukan jumlah anggota setiap kelompoknya; Kemudian kartu diacak dan dibagikan pada siswa masing-masing satu. Setiap siswa ada yang mendapatkan pertanyaan dan ada yang mendapatkan jawaban; Minta setiap siswa untuk menemukan kelompok mereka. Jika ada yang sudah menemukan kelompoknya, minta mereka untuk bergabung dengan kelompoknya; Setiap siswa yang memegang pernyataan akan menemukan pasangannya sejumlah 4 atau 5 orang anggota; Kemudian siswa diminta untuk mendiskusikan pernyataan dan jawaban yang sudah didapat dalam kelompok tersebut; Setelah didiskusikan dengan teman satu kelompok lalu salah satu anggota di masing-masing kelompok diminta untuk mempresentasikannya secara bergantian; Di setiap akhir presentasi kelompok lain diberi kesempatan untuk bertanya atau menyanggah; Guru memberikan penjelasan dan klarifikasi serta kesimpulan materi.

Motivasi merupakan tenaga pendorong seseorang untuk melakukan sesuatu sesuai dengan tujuan yang ditetapkan. Oleh sebab itu, motivasi merupakan bagian yang sangat penting dalam suatu lembaga atau diri seseorang untuk mencapai suatu prestasi. Indikator-indikator motivasi dalam belajar adalah sebagai berikut: a) adanya semangat belajar, b) adanya rasa senang, c) memiliki tujuan yang terarah, d) memiliki kegigihan dalam belajar, e) adanya minat, f) adanya keseriusan, g) adanya kreatifitas, h) tidak ada unsur tekanan dan i) ketepatan menyelesaikan tugas. Motivasi yang memiliki pengaruh paling besar yang mendorong kemauan belajar merupakan motivasi yang datangnya dari dalam diri sendiri, yang biasa disebut dengan motivasi internal. Motivasi ini memerlukan niat dan tekad dari dalam diri agar dapat memunculkan sikap atau perilaku belajar. Jika sudah timbul komitmen belajar akan mendorong terwujudnya prestasi belajar. Guru diharapkan dapat berperan sebagai motivator dari luar bagi semua peserta didiknya, yang mampu meningkatkan motivasi belajar dari dalam diri siswa.

Prestasi belajar siswa merupakan suatu keadaan yang dicapai oleh siswa dengan ditunjukkan oleh bertambahnya penguasaan baik pengetahuan, ketrampilan maupun sikap siswa yang terdapat di dalam kurikulum sekolah. Begitu banyak faktor yang dapat mempengaruhi prestasi belajar peserta didik, baik faktor internal maupun faktor eksternal. Namun demikian dalam penelitian ini dibatasi meliputi dalam hal motivasi belajar siswa.

Dari beberapa faktor yang mempengaruhi prestasi belajar siswa, hal yang perlu diperhatikan adalah faktor yang ada dari dalam diri (internal). Faktor internal ini memegang peran yang sangat penting, karena walaupun faktor eksternal mendukung namun faktor dari dalam diri tidak ada maka perilaku belajar yang baik tidak mungkin terlaksana. Keadaan yang tidak mendukung banyak sekali terjadi di luar sana, namun bila seseorang memiliki intelegensi, sikap, bakat dan motivasi yang kuat, semua hal yang diharapkan bisa saja tercapai, termasuk dalam hal prestasi belajar ini. Apabila siswa memiliki faktor dalam diri tersebut, tantangan seperti apa pun yang datang dari luar tidak akan melemahkannya dalam meraih cita-cita. Dalam penelitian ini penulis hanya membatasi faktor dari dalam diri siswa yang berupa motivasi belajar. Pembelajaran PKn adalah suatu proses interaksi antara pendidik dan peserta didik dalam menggali dan menghayati hak-hak warganegara yang asasi dengan harapan agar setiap peserta didik pada akhirnya akan dapat menyadari hak-haknya yang asasi, yang perlindungannya dijamin oleh undang-undang negara. Perlindungan dan Penegakan Hak Asasi 
Manusia (HAM) meliputi Hakikat, Hukum, dan Kelembagaan Hak Asasi Manusia; Kasus Pelanggaraan dan Upaya Penegakan HAM; Upaya Perlindungan HAM. Strategi pembelajaran Card Sort kolaborasi Small Group Discussion merupakan salah satu strategi pembelajaran yang mampu mengaktifkan siswa, sehingga perlu diterapkan oleh guru sebagai upaya meningkatkan motivasi dan prestasi belajar siswa dalam proses pembelajaran materi perlindungan dan penegakan hak asasi manusia (HAM). Penerapan strategi ini akan menambah partisipasi siswa, berpendapat dan berdiskusi dalam pembelajaran di kelas khususnya dalam proses pembelajaran PKn.

Kerangka pemikiran dalam penelitian ini adalah: Penggunaan metode Card Sort kolaborasi Small Group Discussion akan mengaktifkan siswa pada waktu mengikuti materi perlindungan dan penegakan hak asasi manusia (HAM). 1) Penggunaan metode Card Sort kolaborasi Small Group Discussion akan mampu meningkatkan motivasi dan prestasi belajar siswa dalam bertanya, berpendapat, dan berdiskusi serta dalam mengikuti proses pembelajaran PKn materi perlindungan dan penegakan hak asasi manusia (HAM). 2) Adanya keterkaitan antara penggunaan metode Card Sort kolaborasi Small Group Discussion dengan peningkatan motivasi dan prestasi belajar dalam bertanya, berpendapat, dan berdiskusi serta dalam mengikuti proses pembelajaran PKn pada materi perlindungan dan penegakan hak asasi manusia (HAM). Hipotesis yang akan diajukan oleh peneliti adalah "diduga dengan penggunaan metode Card Sort kolaborasi Small Group Discussion dapat meningkatkan motivasi dan prestasi belajar dalam proses pembelajaran PKn materi perlindungan dan penegakan hak asasi manusia (HAM) pada siswa Kelas VII.3 SMP Negeri 3 Surakarta Tahun 2014/2015".

\section{METODE PENELITIAN}

Tempat penelitian ini adalah di SMP Negeri 3 Surakarta Semester II Tahun Ajaran 2014/2015. Pemilihan tempat tersebut didasarkan pada pertimbangan (1) mudah untuk memperoleh data-data yang dibutuhkan, (2) komunikasi dengan pihak sekolahan relatif mudah. Penelitian ini berlangsung selama empat bulan, yaitu bulan Pebruari sampai dengan Mei 2015. Subjek penelitian tindakan ini adalah siswa SMP Negeri 3 Surakarta. Yaitu siswa kelas VII.3, siswa kelas tersebut berjumlah 32 siswa. Sementara itu, guru dijadikan sebagai mitra kolaborasi dalam melaksanakan PTK. Penelitian tindakan kelas secara garis besar terdapat empat tahapan, yaitu (1) perencanaan, (2) pelaksanaan, (3) pengamatan, dan (4) refleksi. Data penelitian ini dikumpulkan dari berbagai sumber antara lain: informan atau narasumber, yaitu guru dan siswa kelas VII.3 SMP Negeri 3 Surakarta; tempat dan peristiwa berlangsungnya aktivitas pembelajaran materi perlindungan dan penegakan hak asasi manusia (HAM) berada di SMP Negeri 3 Surakarta. Pengumpulan data yang digunakan dalam penelitian ini adalah metode observasi, dengan observasi peneliti dapat mengetahui kegiatan peserta didik dalam mempersiapkan, memperhatikan, presentasi dan motivasi dan prestasi belajar dalam bertanya serta berpendapat selama proses pembelajaran berkaitan dengan tentang penggunaan metode Card Sort Kolborasi Small Group Disscusion sebagai upaya peningkatan motivasi dan prestasi belajar siswa kelas VII.3 SMP Negeri 3 Surakarta Semester II Tahun Ajaran 2014/2015. Metode wawancara (interview), Wawancara yang digunakan dalam penelitian ini, adalah dengan mengajukan pertanyaan-pertanyaan yang tidak terstruktur karena peneliti tidak menggunakan pedoman wawancara yang di susun secara sistematis dan lengkap untuk mengumpulkan datanya sehingga wawancara bebas. Dalam metode ini digunakan untuk memperoleh hasil dari penggunaan metode Card Sort Kolaborasi Small Group Disscusion sebagai upaya peningkatan motivasi dan prestasi belajar siswa kelas VII.3 SMP Negeri 3 Surakarta Semester II Tahun Ajaran 2014/2015. Metode dokumentasi: metode ini menghemat waktu, karena dapat dilihat secara langsung sekaligus mencatatnya; tidak perlu pengantar orang lain; tidak menimbulkan kecurigaan; dapat mengetahui data yang berlalu. 
Ada beberapa teknik yang dapat digunakan untuk mengetahui validitas data (kestabilan data). Penelitian ini menggunakan dua macam triangulasi, yang pertama triangulasi sumber data yang berupa informasi dari guru dan siswa tentang tindakan yang diterapkan. Kedua triagulasi teknik atau metode pengumpulan dari hasil observasi dan wawancara. Adapun yang menjadi indikator dalam penelitian ini adalah penguasaan materi perlindungan dan penegakan hak asasi manusia (HAM) pada siswa kelas VII.3 SMP Negeri 3 Surakarta Semester II tahun 2014/2015 meningkat. Motivasi dan prestasi belajar siswa pada pembelajaran tentang materi kemerdekaan mengemukakan pendapat diharapkan meningkat 75\% melalui penggunaan metode Card Sort kolaborasi Small Group Discussion. Pencapaian indikator tersebut dicapai dengan penggunaan metode Card Sort kolaborasi Small Group Discussion

\section{HASIL DAN PEMBAHASAN}

Perlindungan dan Penegakan Hak Asasi Manusia (HAM) merupakan bagian materi pelajaran PKn di SMP kelas VII semester II. Berdasarkan pengalaman guru sebagai mitra kolaborasi, jumlah siswa kelas VII.3 yang aktif dalam bertanya maupun berpendapat berjumlah kurang lebih hanya 12 siswa atau 37,5\% dari keseluruhan siswa yang berjumlah 32 siswa. Pemahaman siswa pada materi ini juga kurang maksimal. Hal tersebut dikarenakan motivasi dan prestasi belajar siswa pada waktu mengikuti materi ini, yang sesuai indikator sangat kurang. Jumlah siswa dalam satu kelas adalah 32 siswa, dari jumlah tersebut hanya 12 yang aktif dalam mengikuti materi perlindungan dan penegakan hak asasi manusia (HAM) baik yang bertanya dan berpendapat (hasil pengamatan peneliti ) sebagai mitra kolaborasi sebelum penggunaan metode Card sort kolaborasi Small Group Disscussion pada materi perlindungan dan penegakan hak asasi manusia). Ketidakaktifan siswa dalam bertanya dan berpendapat pada materi perlindungan dan penegakan hak asasi manusia (HAM) berdampak pada kurangnya pemahaman siswa terhadap materi tersebut. Dengan demikian apa yang menjadi tujuan materi pelajaran tersebut akan sulit tercapai. Untuk itu peneliti mengajukan strategi pembelajaran Card sort kolaborasi Small Group Disscussion sebagai upaya meningkatkan motivasi dan prestasi belajar siswa. Alasan dipilihnya strategi pembelajaran Card Sort kolaborasi Small Group Disscussion karena strategi ini memiliki beberapa kelebihan dibandingkan dengan strategi lainnya. Kelebihan strategi pembelajaran ini antara lain siswa akan lebih aktif dalam mengikuti pelajaran karena setiap siswa akan terlibat dalam mempresentasikan salah satu kategori yang berisi informasi yang mencakup materi yang sudah disampaikan. Dengan demikian motivasi dan prestasi belajar siswa dalam mengikuti pelajaran dapat meningkat.

Penelitian mulai dilaksanakan pada bulan Pebruari 2015, diawali dengan pengamatan awal peneliti sebagai guru PKn Kelas VII.3. Pengamatan awal dilaksanakan pada hari Senin,5 Januari pukul 10.00 WIB di kelas VII.3 SMP Negeri 3 Surakarta untuk menentukan kelas sampel dalam penelitian ini yaitu kelas VII.3. Selanjutnya peneliti sebagai mitra kolaborasi melakukan dialog untuk mengetahui permasalahan yang ada pada kelas tersebut. Berdasarkan pengalaman peneliti dalam mengajar materi Perlindungan dan penegakan hak asasi manusia (HAM) mengamati secara langsung di kelas, maka peneliti sebagai guru PKn menyimpulkan permasalahan yang ada pada kelas VII.3 adalah rendahnya kemampuan bertanya dan berpendapat siswa khususnya pada materi pelajaran Perlindungan dan penegakan hak asasi manusia (HAM). Hal tersebut terlihat pada kurangnya motivasi dan prestasi belajar siswa baik dalam bertanya maupun berpendapat pada materi pelajaran tersebut.

Setelah kegiatan merumuskan masalah di atas, dilanjutkan dengan mengidentifikasi faktor-faktor penyebab masalah. Hasil kerja analisa awal peneliti sebagai guru Pkn kelas VII.3 dan peneliti menetapkan bahwa penyebab masalah adalah peserta didik pasif dalam menerima informasi maupun dalam proses pembelajaran, sulit mengutarakan ide atau gagasan, menganggap remeh pelajaran PKn, 
kurangnya motivasi siswa. Guru kurang membantu siswa mencapai tujuan, kurang memberi motivasi, kurang mendorong siswa untuk mengeluarkan pendapat. Proses pembelajaran masih berpusat pada guru dan cenderung satu arah. Penyampaian materi ajar kurang variatif dan kurang kompleks.

Berdasarkan berbagai kemungkinan penyebab masalah yang dijelaskan di atas kemudian dapat diambil sebuah kesimpulan bahwa penyebab masalah yang paling dominan adalah pembelajaran yang cenderung satu arah, sehingga berpusat pada guru dalam proses pembelajaran. Oleh karena itu faktor penyebab masalah yang telah disepakati oleh rekan kolaborasi, kegiatan dilanjutkan dengan dialog untuk membahas perencanaan solusi masalah yang telah dikembangkan. Pembahasan perencanaan solusi masalah ini dilakukan dalam satu rangkaian dialog awal kedua yaitu pada hari Sabtu, 31 Januari 2015. Tindakan solusi masalah yang diaplikasikan dalam penelitian ini adalah melalui penggunaan metode pembelajaran Card Sort kolaborasi Small Group Disscussion dapat meningkatkan kemampuan bertanya dan berpendapat pada siswa dalam materi pelajaran Perlindungan dan penegakan hak asasi manusia (HAM). Tindakan pembelajaran dengan penggunaan metode pembelajaran Card Sort kolaborasi Small Group Disscussion akan diterapkan pada peserta didik kelas VII.3 yang akan dikembangkan pada setiap siklus tindakan melalui perencanaan yang terevisi. Penggunaan metode Card Sort kolaborasi Small Group Disscussion diharapkan dapat mengubah pembelajaran yang semula peserta didik hanya pasif menjadi lebih aktif dalam bertanya maupun berpendapat. Selanjutnya pembelajaran yang semula hanya berpusat pada guru akan berubah menjadi pembelajaran yang berpusat pada peserta didik dan guru hanya sebagai fasilitator saja. Selanjutnya peneliti menyusun proposal penelitian dan melaporkan kepada kepala sekolah yang sekaligus mohon ijin penelitian.

Pembahasan terhadap permasalahan penelitian maupun hipotesis tindakan berdasarkan analisis data kualitatif hasil penelitian dari kolaboratif antara peneliti dan praktisi pendidikan dan tanggapan guru PKn yang terlibat dalam kegiatan ini, serta profil kelas sebelum dan sesudah penelitian yang dibuat oleh guru yang melakukan tindakan kerja kolaborasi dimulai dari: (1) perencanaan tindakan, (2) pelaksanaan tindakan, (3) pengamatan tindakan, (4) refleksi hasilnya sebagai berikut, tentang proses pembelajaran dengan metode Card Sort kolaborasi Small Group Disscussion dan hasil penelitian yang dilakukan secara kolaboratif antara peneliti, guru kelas dan kepala sekolah menyatakan bahwa dalam proses pembelajaran pada materi Perlindungan dan penegakan hak asasi manusia (HAM) dengan menggunakan metode Card Sort kolaborasi Small Group Disscussion telah memberikan dorongan kepada guru untuk mengembangkan model pembelajaran baru yang inovatif dalam melakukan pembelajaran yang mengikutsertakan peserta didik, sehingga dalam proses pembelajaran tidak berpusat pada guru dan peserta didik juga bisa bersosialisasi dengan peserta didik yang lainya.

Pembelajaran dengan menggunakan metode Card Sort kolaborasi Small Group Disscussion ini meminta peserta didik aktif berinteraksi dengan sesama temannya, sehingga mereka lebih aktif dalam bertanya maupun berpendapat agar lebih mudah memahami materi dan terlibat langsung dalam proses pembelajaran. Berkaitan dengan kemampuan bertanya dan berpendapat pada materi Perlindungan dan penegakan hak asasi manusia (HAM) peserta didik, dengan adanya metode Card Sort kolaborasi Small Group Disscussion ini secara perlahan-lahan kemampuan bertanya dan berpendapat peserta didik dalam mengikuti pelajaran mengalami peningkatan disetiap tindakan kelas yang dilakukan oleh peneliti. Peserta didik menjadi semakin "mampu" dalam arti peserta didik semakin aktif dalam menyampaikan pertanyaan atau pendapat disetiap mengikuti pelajaran. Oleh karena itu maka siswa benar-benar memahami pengetahuan yang diberikan oleh guru sehingga kemampuan menguasai materi ajar dapat maksimal. 
Melalui metode Card Sort kolaborasi Small Group Disscussion ini dapat meningkatkan partisipasi dan motivasi dan prestasi belajar siswa dalam pembelajaran materi Perlindungan dan penegakan hak asasi manusia (HAM), guru kelas VII.3 melakukan pembenahan pelaksanaan tindakan pada saat proses belajar mengajar. Pembenahan tindakan tersebut adalah dengan mengaktifkan siswa. Motivasi dan prestasi belajar peserta didik dalam bertanya, sebelum penelitian hanya 12 peserta didik yang berani bertanya dan berpendapat apabila mengalami kesulitan, pada siklus I dalam mengajukan pertanyaan dan berpendapat meningkat menjadi $12(37,5 \%)$ peserta didik. Kemudian peneliti mengadakan revisi dan evaluasi lagi untuk mendapatkan hasil yang optimal dan akhirnya peneliti melaksanakan siklus II dan didapatkan hasil $25(78,13 \%)$ peserta didik yang berani dan mampu mengajukan pertanyaan dan berpendapat. Untuk mengaktifkan peserta didik juga dilakukan penambahan pembimbing atau pengawas yang berperan untuk membantu guru kelas dalam memberikan penjelasan dan motivasi kepada siswa agar siswa lebih aktif dalam proses pembelajaran.

Tingginya keterlibatan peserta didik dalam pembelajaran dapat mendorong peserta didik untuk mengemukakan idenya tanpa ada paksaan dalam proses pembelajaran. Siswa dapat secara bebas menyatakan ketidak setujuannya tentang pendapat yang disampaikan oleh temanya. Peneliti menawarkan model pembelajaran baru kepada guru yaitu dengan menggunakan metode Card Sort kolaborasi Small Group Disscussion dan hasilnya terlihat pada siklus I yaitu sebanyak 16 (50 \%) peserta didik yang mau bertanya dan berpendapat dengan baik, kemudian setelah dilaksanakan siklus I peneliti mengadakan evaluasi dan revisi untuk melaksanakan siklus II dan akhirnya ada peningkatan siswa dalam bertanya dan berpendapat yang cukup signifikan yaitu sebanyak 25 (78,13\%) peserta didik.

Melalui metode Card Sort kolaborasi Small Group Disscussion dapat terlihat bagaimana peningkatan kemampuan bertanya dan berpendapat peserta didik mulai dari sebelum penelitian hingga penelitian berakhir. Tingkat motivasi dan prestasi belajar siswa dalam bertanya dan berpendapat kelas VII.3 SMP Negeri 3 Surakarta tahun 2015, yaitu sebanyak $12(37,5 \%)$ siswa. Setelah dilakukan tindakan yang disepakati yaitu dengan menerapkan metode Card Sort kolaborasi Small Group Disscussion pada pembelajaran diperoleh hasil yaitu siklus I meningkat menjadi 16 (50\%) siswa. Jumlah tersebut dalam kategori kurang berhasil. Setelah dilakukan tindakan yang direvisi pada siklus II diperoleh hasil untuk jumlah siswa yang aktif bertanya dan berpendapat meningkat menjadi $25(78,13$ $\%)$ siswa.

Selama proses pembelajaran berlangsung, kualitas pembelajaran pada tiap siklusnya mengalami peningkatan secara bertahap dan pada akhirnya dapat meningkatkan kemampuan bertanya dan berpendapat siswa. Pada siklus I, belum didapatkan hasil yang memuaskan. Hal ini disebabkan keadaan siswa yang masih belum mengerti maksud dan tujuan yang mereka lakukan. Siswa masih asing dengan pembelajaran dengan metode Card Sort kolaborasi Small Group Disscussion. Pembelajaran tindakan kelas siklus II berjalan lebih baik jika dibandingkan dengan tindakan siklus I. Hasil yang dicapai juga meningkat, hal ini karena siswa sudah mengetahui tahap-tahap dalam strategi pembelajaran dengan metode Card Sort kolaborasi Small Group Disscussion. Gambar berikut adalah siklus perkembangan penerapan metode Card Sort kolaborasi Small Group Disscussion dalam upaya untuk meningkatkan kemampuan bertanya dan berpendapat siswa mulai dari kondisi awal sampai pada tindakan siklus II. 


\section{KESIMPULAN}

Dari rangkaian putaran penelitian tindakan kelas yang telah dilakukan terlihat adanya perubahan yang merupakan hasil penelitian dalam rangka usaha meningkatkan kemampuan siswa dalam bertanya dan berpendapat pada materi Perlindungan dan penegakan hak asasi manusia (HAM). Bertitik tolak dari tindakan yang telah dilaksanakan pada penelitian ini, maka dapat memberikan beberapa kesimpulan yaitu penerapan metode Card Sort kolaborasi Small Group Disscussion telah mampu meningkatkan kemampuan bertanya dan berpendapat siswa pada materi Perlindungan dan penegakan hak asasi manusia (HAM) hingga sebanyak 20 siswa (74,1\%). Peningkatan kemampuan bertanya dan berpendapat siswa diamati melalui kegiatan diskusi kelompok dan presentasi di depan kelas. Kemampuan siswa dalam bertanya dan berpendapat meningkat yaitu sebelum adanya penelitian siswa yang aktif bertanya dan berpendapat sebanyak 10 atau $37,7 \%$ siswa Pada putaran I sebanyak 12 atau $44,4 \%$ siswa, pada putaran II sebanyak 20 atau $74,1 \%$ siswa. Implikasi bahwa penggunaan metode Card Sort kolaborasi Small Group Disscussion dapat meningkatakan motivasi dan prestasi belajar siswa pada materi Perlindungan dan penegakan hak asasi manusia (HAM). Pembelajaran dilakukan dengan memberikan motivasi-motivasi kepada siswa. Peningkatan motivasi dan prestasi belajar bertanya dan berpendapat serta menjawab pertanyaan siswa pada materi Perlindungan dan penegakan hak asasi manusia (HAM) dapat dilakukan dengan cara mengajak siswa untuk berperan aktif diskusi kelas dan diskusi kelompok untuk mengemukakan idenya dalam hal mendefinisikan konsep secara tepat. Hasil penelitian ini dapat digunakan sebagai masukan bagi guru dan calon guru untuk mengoptimalkan peran siswa dalam belajar. Jika siswa sudah dapat menunjukkan bahwa mereka dapat menganggap dirinya sebagai guru untuk temannya dan teman mereka sebagai guru maka hasil belajar berupa kemampuan siswa akan meningkat.

\section{SARAN-SARAN}

Berdasarkan analisis terhadap tingkat keberhasilan siswa kelas VII SMP Negeri 3 Surakarta dalam menyelenggarakan kegiatan belajar mengajar, dapat disarankan sebagai berikut: (1) Hendaknya diperbanyak pelatihan kepada guru-guru tentang model-model pembelajaran, agar kegiatan belajar mengajar lebih kreatif dan inovatif. (2) Kepala Sekolah perlu mengadakan Standar Operasional Pelaksanaan bagi guru- guru SMP Negeri 3 Surakarta agar lebih terarah dan memberikan hasil optimal bagi peserta didik. (3) Perlu diperbanyak kegiatan MGMP guru bidang studi, bisa kerjasama dengan pihak luar yang kompeten di bidangnya. (4) Kepala Madrasah perlu mengadakan Monitoring dan evaluasi secara rutin dan dibahas dalam forum rapat untuk ditindak lanjuti. (5) Kepala Madrasah perlu menyiapkan media pembelajaran agar kegiatan KBM berjalan dengan lancar dan sesuai dengan target.

\section{DAFTAR PUSTAKA}

Darmansyah, S.T., M,Pd. (2010). Strategi Pembelajaran Menyenangkan Dengan Humor. Jakarta:Bumi Aksara

Silberman, M. 2001. Active Learning (101Strategi Pembelajaran Aktif).Yogyakarta: Pustaka Insan Madani.

Sunaryo. 1989. Strategi Belajar Mengajar dalam Pengajaran Ilmu Pengetahuan Sosial.Jakarta: Debdikbud Direktorat Jenderal Pendidikan Tinggi Objek Pengembangan Lembaga Pendidikan Tenaga Kependidikan.

Suwarsih Madya. (2007). Teori dan Praktik Penelitian Pendidikan (Action Research). Bandung: Alfabeta. 